\title{
Students' Perception on the Use of Socrative in the Middle Test
}

\author{
Viriana \\ SMPN 48 Surabaya, email: annarosyadi@gmail.com \\ Nurul Hakimah \\ SMPN 48 Surabaya, email: hakimahabid@gmail.com
}

\begin{abstract}
Due to the Covid 19 pandemic, teachers are forced to be able to integrate technology into the classroom to ensure the teaching learning continuity, since the face to face in the classroom is not possible during pandemic. Thus, Socrative is used to conduct the middle test. The online examinations are used as a solution to make the school program still go on. This study focuses on students' perceptions on the use of Socrative in the middle test. The research involved 80 participants consisting of 42 students of 8 th and 38 students of $7^{\text {th }}$ class from SMPN 48 Surabaya East Java. The data were collected through questionnaires and were analyzed to get the students perception. The results of the study indicated that majority of participants considered the use of Socrative in the middle test practical, effective and efficient in terms of time. Although slow-speed internet is considered to be one of difficulties in using Socrative, most of the participants agreed that the examination online enable them to get new and powerful learning experience.
\end{abstract}

Keywords: Socrative, online examination, student perception

\section{INTRODUCTION}

Teaching nowadays is different from teaching in the past. Teachers have to face the technology that is growing so fast and the Generation $\mathrm{Z}$ students, also known as PostMillennials. Generation z processes information fasterthan other generations. They are familiar with gadgets, computers and many kinds of interesting applications. This technology is their lives and they can't live without. Teachers have to adapt the teaching process using the technology to make their students interested in the lessons.

Moreover Covid-19 Pandemic that occurred around the world since early January 2020 has forced all schools activities to be stopped to prevent the spread of disease due to the corona virus. School activities may stop, but learning activities must continue. Using technology can be used as the alternative in teaching and learning process. Teaching language using technology can help students to get better understanding. Based on (Online Tools for Teaching and Learning, 2020) It is helpful to think of the computer as having the following main roles in the language classroom: teacher -the computer teaches students new language. 
Computers as a tool, it assists students to do certain tasks. Data sourcethe computer provides students with the information they need to perform a particular task. Computer Assisted Language Learning (CALL) is essentially a tool that helps teachers to facilitate the language learning process. It can be used to reinforce what has already been learned in the classroom or as a remedial tool to help learners who require additional support. Socrative is one of the CALL.

Socrative is a cloud-based student response system developed in 2010 by Boston-based graduate school students. It allows teachers to create simple quizzes that students can take quickly on laptops - or, more often, via classroom tablet computers or their own smartphones (Socrative Home, 2020). Acording to (Beatty, 2010) CALL much has changed in the twentyfirst century. Among the greatest changes is the integration of computing facilities into many aspects of daily life. Mobile telephones, satisfy many of the computing demands of average users. Students as the z generation can't be separated from their mobile phones. Teaching Learning is much easier using mobile phones since it very acknowledges for students and teachers. It also can be used at home in a pandemic condition that requires no physical contact between humans.

\section{Socrative as the Teaching Tools}

Socrative is an interactive web-based student-response system (also available through iOS, Android, or Chrome apps) that can help teachers spark conversation and learning through user-created polls and quizzes. Students access questions via a Room code, and answers register immediately on the teacher's computer as the students submit their responses on almost any device. When everyone has responded, teachers can display the results using the "How did we do?' button. Teachers can create quizzes, quick questions, and exit slips that allow for multiplechoice, true/false, and one-sentence-response questions that can be graded with feedback for each student. Students can also work together to play the Space Race, which is a collaborative activity so students can answer questions quickly in the team; the teacher can easily access realtime results from this competition and can determine the student team. Then the teacher can see the quiz data on Microsoft Excel and download it. If further action is needed, the teacher can also send it via email (Marianne Rogowski, 2018).

Socrative can be accessed on the top three operating systems: Windows, Apple, and Chrome. No downloads are required. A web browser that utilizes HTML-5 is needed to access all functions. Socrative is also usable on various hardware: desktops, smartphones, tablets, and mobile phones. Socratives can be used by teachers and students. It can be used for students inkindegarten until grade 12. Socrative provides an opportunity for all students-regardless of 
level - to track and understand their progress. This is to increase equality in education, because teachers can hone students with challenging content. Lesson plans can be arranged better because of the feedback feature provided by Socrative, in the form of a report from Socrative. Quizzes can also be given to give students richer learning experiences (Online Tools for Teaching and Learning, 2020).

\section{How to Use Socrative}

Teachers can create account for free. After creating a free account, teachers are automatically given one public room. The public room is, essentially, a virtual meeting place for teachers and students. Within a public room, teachers can create a quiz, search for a quiz, copy a previous quiz, edit quizzes, and more. Question types can be multiple choice, true/false, or short answer, and question order can be shuffled for each student. While images can be uploaded to a quiz, there is no support for audio or video files. Unfortunately, a public room cannot accommodate a class roster. In order to track student activity within a public room, students must first enter the name of the public room, followed by their personal name.

Students do not need to create accounts. Teachers invite students via a URL into a room to access a quiz, quick question, space race, or exit ticket. Socrative maintains a reports section, where teachers can download an Excel spreadsheet with data on overall class performance. Individual student reports are also available to download in PDF format. Aggregate and individual results can also be e-mailed to teachers. The Quick Question feature allows students to answer multiple choice, true/false, or open-ended questions in real-time. this makes it easy for teachers to know how students are performing in their class throughout the lesson. Checking students with Quick Questions allows teachers to adjust learning so that the objectives to be achieved are met. The results of work in class can be shared with students instantly.

The Exit ticket is an assessment in the form of a quiz given at the end of the lesson. This quiz is to find out whether students have mastered the material and learning objectives have been achieved. Students can exit the Exit Ticket to correct homework or resolve errors. The Space Race is the feature that is allowed the teacher to make quizzes and form groups of students to compete in their work. If students or teams can answer each quiz question, the avatar of their choice moves forward in the race. The winner is the one who answers the most correctly in the timeframe specified on the quiz (Socrative Home, 2020).

\section{The Socrative Strength and Weakness}

Before we discuss the strength and the weakness of Socrative application, it is better to know socrative compare to other similar applications such as Kahoot and Quizizz. Here is the 
table shows comparison among Socrative, Kahoot and Quizizz based on (Pilakowski, 2017).

Table 1. Comparison of Socrative, Kahoot and Quizizz

\begin{tabular}{|c|c|c|c|}
\hline $\mathbf{A P P}$ & SOCRATIVE & KAHOOT & QUIZIZZ \\
\hline Overall Purposes & $\begin{array}{l}\text { For longer answers } \\
\& \text { amp; student } \\
\text { pacing (must use } \\
\text { synchronous pacing } \\
\text { for Space Race) }\end{array}$ & $\begin{array}{l}\text { To create high } \\
\text { energy \& amp; } \\
\text { encourage } \\
\text { (generally) quick } \\
\text { recall }\end{array}$ & $\begin{array}{l}\text { To allow for student- } \\
\text { pacing (and stress- } \\
\text { free thinking time if } \\
\text { you choose to shut } \\
\text { off timer) }\end{array}$ \\
\hline $\begin{array}{l}\text { Question/Quiz } \\
\text { Library }\end{array}$ & $\begin{array}{l}\text { Website states } \\
\text { searchable quizzes } \\
\text { are forthcoming }\end{array}$ & $\begin{array}{l}\text { Over a million } \\
\text { quizzes to copy and } \\
\text { edit as your own }\end{array}$ & $\begin{array}{l}\text { Large library, plus } \\
\text { ability to search and } \\
\text { select individual } \\
\text { questions during } \\
\text { quiz creation }\end{array}$ \\
\hline Timers & $\begin{array}{l}\text { Ranges from 5-120 } \\
\text { seconds }\end{array}$ & $\begin{array}{l}\text { Can shut timer off } \\
\text { completely }\end{array}$ & No Timer \\
\hline Player Leaderboard & No & $\begin{array}{l}\text { Limited to top } 5 \text {. It } \\
\text { also provides } \\
\text { recognition for } \\
\text { improvers. }\end{array}$ & $\begin{array}{l}\text { Yes, but may be shut } \\
\text { off. }\end{array}$ \\
\hline PIN Numbers & $\begin{array}{l}\text { The same one is } \\
\text { used for each } \\
\text { classroom and } \\
\text { doesn't change. }\end{array}$ & $\begin{array}{l}\text { A new one is } \\
\text { generated for each } \\
\text { quiz. }\end{array}$ & $\begin{array}{l}\text { A new one is } \\
\text { generated for each } \\
\text { quiz. }\end{array}$ \\
\hline $\begin{array}{l}\text { Randomize } \\
\text { Question }\end{array}$ & Yes & Yes & Yes \\
\hline $\begin{array}{l}\text { Feedback to } \\
\text { Answer }\end{array}$ & $\begin{array}{l}\text { Teachers may write } \\
\text { unique automated } \\
\text { feedback for } \\
\text { questions }\end{array}$ & $\begin{array}{l}\text { The correct answer } \\
\text { is given }\end{array}$ & $\begin{array}{l}\text { May program the } \\
\text { correct answer to be } \\
\text { shown, or shut it } \\
\text { off. Memes are used } \\
\text { to indicate whether } \\
\text { correct or incorrect. }\end{array}$ \\
\hline Math Mode & Yes & Yes & Yes \\
\hline $\begin{array}{l}\text { Multiple Answer } \\
\text { Correct }\end{array}$ & Yes & No & Yes \\
\hline Reports & Downloadable & $\begin{array}{l}\text { Downloadable and } \\
\text { view online }\end{array}$ & $\begin{array}{l}\text { Downloadable and } \\
\text { view online }\end{array}$ \\
\hline Others & $\begin{array}{l}\text { Short answer } \\
\text { questions available }\end{array}$ & $\begin{array}{l}\text { New Jumble and } \\
\text { Ghost Mode are } \\
\text { new innovations. } \\
\text { Blind Kahoot can } \\
\text { be used for direct } \\
\text { instruction. } \\
\text { Videos can be } \\
\text { included. }\end{array}$ & $\begin{array}{l}\text { Avatars assigned to } \\
\text { each player. } \\
\text { Custom meme } \\
\text { option available }\end{array}$ \\
\hline
\end{tabular}

From the table above we know that each application has its own little benefits and 
specialties, teachers have to choose the one that's going to fit their objectives. Which one is better? The answer is, it depends what the teachers want it to do. Ultimately, it comes down to what teachers want to do with the app, for each one has its own benefits for the classroom.

Socrative is currently a free application. Although socrative is quick to learn it has limitations (1) Student assessment results are not connected with the assessment before and after, so the teacher can not monitor student progress. This is a drawback of this application. (2) The interface in this application is operating less smoothly, and sometimes unresponsive. This results in students often having to log out and log back in (3) Class projector displays are limited and less attractive making it more difficult to attract class attention (4) Socrative does not have sophisticated features such as data about declining student performance, achievement and progress achieved by students, and the absence of other data beyond the average assessment that can be used by teachers to evaluate learning.

Socrative also has strengths in using it (1) It is free application available on Android, iOS, or as website (2) Easy to learn for both teachers and students (3) Integrated with Edmodo (not free) (4) Socrative is a comprehensive application. Teachers can create a series of polling questions around topics such as learning in the technology era, discussions about Covid 19, or involve students in reviewing the concepts of last week's lessons and preparing for this week's lessons.

The objective of this study was to provide insights on students' perception on the use of Socrative for cond ucting the middle test when the students had to stay at home during pandemic. Thus, the study seeks to achieve aforementioned objectives and the issues to be discussed in this paper will be summarized in the following Research Questions: 1. What is Socrative? 2. How is the students' perception toward Socrative in the middle test conduct during pandemic era?

\section{METHOD}

\section{Respondents}

The participants for this study are SMPN 48 Surabaya students from class 7 and 8 . A total number of 42 ( 19 males, 23 females) students from class 8I and 38 (15 males, 23 females) students from 7A were given the questionnaire for this study. All of the participants for this study were taken their middle test using Socrative before they were given the questionnaire.

\section{Instruments}

Such a questionnaire was was used. It was asking about students perception after they had done the middle test using Socrative. The survey questions were asking about how the 
students perception toward using Socrative in the middle test. The survey consisted of 21 questions; the first three questions were the students names, class and gender. The following 10 questions were about use the of Socrative in general. The students had to give their opinion about their effort, the cost, internet speed, the lay out and their knowledge on using socrative by giving one answer of 5 answers options Strongly Agree $=\mathrm{SA}$, Agree $=\mathrm{A}$, Neutral $=\mathrm{N}$, Not Agree $=$ NA and Absolutely Not Agree $=$ ANA (see Table.2) .

Table.2 The Questions in the Questionnaire Section 1

\begin{tabular}{|c|l|}
\hline No & \multicolumn{1}{|c|}{ Questions } \\
\hline 1 & Socrative is fun application \\
\hline 2 & $\begin{array}{l}\text { Socrative is more practical than other applications that have been used at school (for } \\
\text { example Office 365) }\end{array}$ \\
\hline 3 & Working on a middle test with Socrative is easy to operate \\
\hline 4 & Socrative should be used in every exam held by the school \\
\hline 5 & The layout of the questions and test answers on the monitor screen is clear \\
\hline 6 & If I make a mistake while operating Socrative, I can go back and recover quickly \\
\hline 7 & Socrative is easy to remember when you use it later \\
\hline 8 & Socrative steps are practical when it is used \\
\hline 9 & Socrative is easily accessed with all internet speeds \\
\hline 10 & Socrative costs a lot of money for the internet \\
\hline
\end{tabular}

Section 2 consisted of 8 questions about the students feeling when they were using internet by giving one answer of 3 answers options (Yes, No, Not Sure). (see Table.3)

Table.3 Question in The Questionnaire Section 2

\begin{tabular}{|c|l|}
\hline No & \multicolumn{1}{c|}{ Questions } \\
\hline 1 & $\begin{array}{l}\text { I think online middle test using Socrative is better than middle test using paper } \\
\text { and pencil (explain why) }\end{array}$ \\
\hline 2 & I'm always anxious when I use Socrative (if the answer yes, why) \\
\hline 3 & My parents support me using Socrative (if the answer No, why) \\
\hline 4 & I think middle test using Socrative makes me more concentrated on doing the test. \\
\hline 5 & I think Socrative is practical and easily accessible with the cellphone I have. \\
\hline 6 & I think Socrative gives me a new and powerful learning experience \\
\hline 7 & $\begin{array}{l}\text { If the teacher asks to do the questions or assignments using Socrative, but does not } \\
\text { require doing them. I will do it happily }\end{array}$ \\
\hline 8 & I want to use Socrative more often to study \\
\hline
\end{tabular}

The questions were about parents' support, their willing to use Socrative in the future, worries, experience, and comparison of offline exams Few questions need further explanation. When they answered "no" for parents' support, they had to explain why their parents didn't support. When they answered "yes" for question about worries they had to explain why the felt that way. They also had to explain the difference between online and offline exams. 


\section{Procedures}

The questionnaire was administered to figure out students' perception and experience towards the use Socrative after using it for doing their middle test, in the second semester, academic year 2019/2020. The survey was conducted by sharing the link of Google Form, and students used their smartphones to answer. The survey was conducted in two classes grade 7 and 8.39 of $8 \mathrm{I}$ students and 37 of 7A students answered survey questions. 3 students from 8I and 1 student from 7A didn't fill out the survey There were several reasons: some could not access the Internet, and some found that the students didn't know the information about the survey because they didn't read the group WhatsApp and couldn't be called, and they changed the number without giving information about their new numbers.

\section{Data Analysis}

The data from students' questionnaire were then computed to find out the percentage of each statement and then it was interpreted descriptively. The students' statements data were all analyzed for supporting the data from the questionnaire. The data were used to provide description of students' perception on the use of Socrative in their middle test and the students experiences and efforts after using the Socrative were also discussed.

\section{RESULTS AND DISCUSSION}

This section presents findings and discussion related to the research questions. Socrative is the teaching tool and an interactive web-based student-response system. It can be used for conducting the examination in pandemic era. Due to the face to face meeting is not allowed during pandemic, Socrative can be used as an alternative to make the school programs can still run such as the middle test.

It is also important to know how the students' perception on using Socrative in their middle test. The discussion is shown through the interpretation of the results shown in the tables elaborated with the findings from further explanation. The results of the study were obtained from 76 participants of 7A and 8I classes junior high school students. The students have used Socrative for doing their middle test at home during Covid 19 pandemic. The students stated that the online exams using Socrative is easy to operate, they can go back easily if they accidently make mistakes, it is also practical compare to another application such as Office 365 , and it should be used in every exams at school in the future. Besides the findings from students' questionnaire is shown on the table as below. 
Table.4 Students Perception on The Use of Socrative in the Middle Test

\begin{tabular}{|c|l|c|c|c|c|c|}
\hline No & \multicolumn{1}{|c|}{ Questions } & $\begin{array}{c}\text { Strongly } \\
\text { Agree }\end{array}$ & Agree & Neutral & $\begin{array}{c}\text { Not } \\
\text { Agree }\end{array}$ & $\begin{array}{c}\text { Absolutely } \\
\text { Not Agree }\end{array}$ \\
\hline 1 & Socrative is fun application & $30 \%$ & $67 \%$ & - & - & - \\
\hline 2 & $\begin{array}{l}\text { Socrative is more practical } \\
\text { than other applications that } \\
\text { have been used at school (for } \\
\text { example Office 365) }\end{array}$ & $28 \%$ & $50 \%$ & $18 \%$ & - & - \\
\hline 3 & $\begin{array}{l}\text { Working on a middle test with } \\
\text { Socrative is easy to operate }\end{array}$ & $34 \%$ & $53 \%$ & $12 \%$ & - & - \\
\hline 4 & $\begin{array}{l}\text { Socrative should be used in } \\
\text { every exam held by the school }\end{array}$ & $26 \%$ & $43 \%$ & $26 \%$ & - & - \\
\hline 5 & $\begin{array}{l}\text { The layout of the questions } \\
\text { and test answers on the } \\
\text { monitor screen is clear }\end{array}$ & $36 \%$ & $54 \%$ & - & - & - \\
\hline 6 & $\begin{array}{l}\text { If I make a mistake while } \\
\text { operating Socrative, I can go } \\
\text { back and recover quickly }\end{array}$ & $21 \%$ & $51 \%$ & $22 \%$ & - & - \\
\hline 7 & $\begin{array}{l}\text { Socrative is easy to remember } \\
\text { when you use it later }\end{array}$ & $24 \%$ & $62 \%$ & $13 \%$ & - & - \\
\hline 8 & $\begin{array}{l}\text { Socrative steps are practical } \\
\text { when it is used }\end{array}$ & $34 \%$ & $58 \%$ & $8 \%$ & - & - \\
\hline 9 & $\begin{array}{l}\text { Socrative is easily accessed } \\
\text { with all internet speeds }\end{array}$ & $22 \%$ & $50 \%$ & $21 \%$ & - & - \\
\hline 10 & $\begin{array}{l}\text { Socrative costs a lot of money } \\
\text { for the internet }\end{array}$ & - & $11 \%$ & $30 \%$ & $45 \%$ & - \\
\hline
\end{tabular}

Table. 4 shows that most respondents $(\mathrm{SA}=30 \%$, Agree $=67 \%)$ in the study agreed that Socrative is fun. The students $(\mathrm{SA}=28 \%$, Agree $=50 \%, \mathrm{~N}=18 \%)$ also thought that Socrative is more practical than other applications that have been used at school i.e Office 365 although there are students who are neutral. The high percentage still can be seen by the students who chose agree (28\%) and strongly agree (50\%). It can be concluded that the high gap between agree and neutral or disagree can indicate that students give positive response to Socrative. It has the correlation to the findings that Socrative has a simple layout $(\mathrm{SA}=36 \%$, Agree $=54 \%$ ) and that is why there is an easy way to come back in when students accidently make mistakes ( $\mathrm{SA}=21 \%$, Agree $=51 \%$ ). Students also think Socrative is practical regarding the Socrative steps ( $\mathrm{SA}=34 \%$, Agree $=58 \%)$, Although there are students who are neutral, the percentage is very low compared to students who are strongly agree and agree. When it comes to Socrative access $77 \%$ students agree and $21 \%$ are neutral that Socrative is also easy to be accessed with all internet speed. The $45 \%$ students don't agree and 30\% students are neutral when they were asked about Socrative costs them for internet connection. 11\% students agree that Socrative costs them for internet connection. 
Table.5 StudentsPerception on The Use of Socrative in the Middle Test

\begin{tabular}{|c|c|c|c|c|}
\hline No & Questions & Yes & Not Sure & No \\
\hline 1 & $\begin{array}{l}\text { I think online middle test using Socrative is } \\
\text { better than middle test using paper } \\
\text { and pencil (explain why) }\end{array}$ & $72 \%$ & $18 \%$ & $10 \%$ \\
\hline 2 & $\begin{array}{l}\text { I'm always anxious when I use Socrative (if } \\
\text { the answer yes, why) }\end{array}$ & $17 \%$ & $14 \%$ & $69 \%$ \\
\hline 3 & $\begin{array}{l}\text { My parents support me using Socrative (if } \\
\text { the answer No, why) }\end{array}$ & $82 \%$ & $17 \%$ & - \\
\hline 4 & $\begin{array}{l}\text { I think middle test using Socrative makes } \\
\text { me more concentrated on doing the test. }\end{array}$ & $69 \%$ & $23 \%$ & $7 \%$ \\
\hline 5 & $\begin{array}{l}\text { I think Socrative is practical and easily } \\
\text { accessible with the cellphone I have. }\end{array}$ & $91 \%$ & & \\
\hline 6 & $\begin{array}{l}\text { I think Socrative gives me a new and } \\
\text { powerful learning experience }\end{array}$ & $96 \%$ & & \\
\hline 7 & $\begin{array}{l}\text { If the teacher asks to do the questions or } \\
\text { assignments using Socrative, but does not } \\
\text { require doing them. I will do it happily }\end{array}$ & $66 \%$ & $25 \%$ & $9 \%$ \\
\hline 8 & I want to use Socrative more often to study & $73 \%$ & $22 \%$ & $5 \%$ \\
\hline
\end{tabular}

Table.5 shows the students opinion about using Socrative. Almost all the students prefer to use Socrative for middle test than paper (72\%), only $10 \%$ students prefer to use paper. $18 \%$ students are not sure whether Socrative is better or not. The Students explanations about why they prefer Socrative because it is easier and practical (33 students), they are not tired of writing the answers ( 6 students) and it can save paper ( 3 students). The students prefer exams using paper said it is because they are familiar with using paper, they are worried about their internet connection, they are happy meeting with the teacher, and they can cheat easily. The students are also familiar with Socrative, they don't feel anxious when using it (69\%). 14\% students are not sure and only $17 \%$ students are anxious because they are afraid of getting a bad score (1 student), bad internet connection ( 9 students), not being able to log back in if it is an error (1 student).

Parents also give their support using Socrative. No student gives the answer "No" for parents support. $69 \%$ students think that Socrative can make them feel more concentrated doing the test. 91\% Students also think they can easily access Socrative with their mobile and 96\% students think they have new and powerful learning experience. Because $73 \%$ students want more often to study using Socrative, $66 \%$ of them are willing to do the assignment from the teachers, even if it isn't required to do it. 


\section{Socrative is the Simple and Easy Teaching Tool}

The data showed that students gave positive responses toward the use of Socrative for conducting their middle test. Most of the respondents of the study gave renponses that they are feel comfortable with Socrative. The students prefer using Socrative than offline exams because Socrative is easier, practical and makes them more concentrated. The students mentioned that they will do the assignment given by the teacher with Socrative although it doesn't require them to do it. Besides Socrative makes them have new experience dan Socrative makes them feel powerful in learning. They also mentioned that it is easier to access with their mobile phones. The students participated in the study agree that by using Socrative is easy to be operated, it can be accessed with all internet speeds, it has good layout and it is easier to log back in just in case they make mistakes Their parents also support them in using it. Most of them agree if all tests at school using Socrative in the future.

Related to the problems on using the online middle test platforms, the participants involved in the study mentioned that the internet connection is the main problem appeared during the use of Socrative. Few stiudents felt that Socrative can not be operated in all internet speeds. They also felt anxious while doing the test with Socrative. With low internet speed, they are afraid of getting troubles during the test and as the result they will get the bad scores. Since the exams were done at home, the techer can not monitor all the students problems. The finding is supported by (Uk Essays, 2017) The disadvantage of the e-examination is the inability of invigilating. There are methodologies used in these examinations, when registering candidates and presentation of questions, so that to test candidates knowledge and skills. However with a limited time, candidate is not capable of totally depend on the reference materials or a supporting person. That is why teachers can not monitor and accompany while the exams are in progress.

The data presented showed that Socrative can help teachers to do the school work i.e the implementation of students evaluation. The examination still can be held online during pandemic. The students also mentioned that the online exams help them to concentrate more, and it is more practical, no paper needs, and save time. The finding is supported by (Uk Essays, 2017) that online exams can be conducted for remote candidates Also online examinations can be conducted at any time and does not incur higher cost as traditional exam scenario as there is no paper work involved e.g printing exam papers, and prepare paper admissions. there is no invigilators, also no need of arrangement of exam centers. Traditional exam scenario cost much compare to the cost for an online examination. The cost for onlizne exams will be almost zero after the online exam system is establishment and if maintenance cost is not considered. Besides 
evaluation of answers can be fully automated for Multiple Choice questions and other essay type questions can be evaluated manually or through automated system, depending on the nature of the questions and the requirements. The online examination system helps in speeding up the process of conducting examination. Teachers will be able to create examinations by composing a set of questions.

\section{CONCLUSION}

Socrative is a fantastic way to move toward a 21 st century learning environment. The findings of the study indicate that students show positive response towards the use of Socrative in their middle test. The students participated in the study perceive online exams using Socrative is practical since they can access it with their own mobiles. It also doesn't cost them much money for internet connection. . Besides, students think that using online examination is effective since it saves time, environment friendly because it saves papers and . integrating technology, they also experience new learning with this technology.

Therefore, we can conclude that since students perceive the use of online examination using Soocrative positively, online examination with Socrative could be explored and used for all kinds of exams at school in the future. Regarding the findings of the study, some recommendations are suggested. For teachers, since the use of online examination platform is promising to be implemented at school, teachers can choose many kinds of test types. Not only for middle, or final test, it can be used for evaluating the students after second class meeting to check the students progress. It can help students to achieve learning objectives. Teachers are also encouraged to be more interactive after online examination process. It will be better if they can give immed iate response and feedback on students'work. Students' difficulties in operating online learning due to their anxiety can be solved by giving them encouragement and understanding of how to be confident during the test. Related to the internet connection as a main problem in using Socrative, parents should provide internet with adequate speeds at home.

\section{REFERENCES}

Uk Essays. (2017, July 05). Retrieved July 02, 2020, from What is Online Examination System?: https://www.ukessays.com/essays/computer-science/overview-on-developing-anonline-examination-system-computer-science-essay.php

Online Tools for Teaching and Learning. (2020). Retrieved April 21, 2020, from Socrative Assessment Tools: https://blogs.umass.edu/onlinetools/assessment-centeredtools/socrative/ 
Socrative Home. (2020). Retrieved April 21, 2020, from Meet Socrative: https://socrative.com/

Beatty, K. (2010). The Emergence of CALL. In K. Beatty, Teaching and Researching, Computer Assissted Language Learning (p. 305). Great Britain: Pearson.

Marianne Rogowski. (2018, October). Socrative Formative and Sumative Assessment Merge in Snapshot Pools and Quizz. Retrieved April 21, 2020, from Common Sense Education: https://www.commonsense.org/education/website/socrative

Pilakowski, M. (2017, June 11). Technology Pursuit Blending Technology into The Language Art Classroom. Retrieved April 21, 2020, from Choosing The Right Q/A Response Games: Kahoot, Quizizz, Qu https://technologypursuit.edublogs.org/2017/06/11/choosing-the-right-qa-response-gamekahoot-quizizz-quizalize-or-socrative/ 